\title{
Evaluation Quality of One Layer Flat Bread Supplemented with Beans and Sorghum Baked on Hot Metal Surface
}

\author{
Hinar A. Seleem, Azza A. Omran* \\ Department of Crops Technology Research, Food Technology Research Institute, Agricultural Research Center, \\ Giza, Egypt \\ Email: azzaa_omran@yahoo.com
}

Received 28 September 2014; revised 16 November 2014; accepted 30 November 2014

Copyright (C) 2014 by authors and Scientific Research Publishing Inc.

This work is licensed under the Creative Commons Attribution International License (CC BY).

http://creativecommons.org/licenses/by/4.0/

c) (i)

Open Access

\begin{abstract}
The present study was carried out to develop the wheat flour nutritional value with good quality of unleavened bread by adding $5 \%, 10 \%$ and $15 \%$ of bean or sorghum flour. Water absorption was increased by addition of bean flour as a result of increase rate of substitution. Dough stability decreased for bean and sorghum blends as the same as increasing addition. Softening gradually increased with increasing the addition of beans or sorghum. Addition of $15 \%$ sorghum had the highest degree of softening compared with wheat control and beans mixtures. The extensibility, elasticity and the energy of produced dough were decreased with addition of beans or sorghum to wheat flour and the reduction increased with increasing the level of substitution. In contrast, addition of beans or sorghum to wheat flour increased the proportional number of the produced dough from 3.25 to 3.62 and from 1.80 to 2.90 for beans and sorghum dough, respectively. Bread supplemented with beans had the highest values in protein, ash and fiber compared with wheat and sorghum bread whereas, bread supplemented with sorghum had the highest values in fat content compared with wheat and beans bread. Sorghum bread had the highest iron and zinc content while beans bread had the highest calcium content. The sensory evaluation showed that different blends of beans and sorghum bread had highly acceptable values of all characteristics comparing with wheat control bread. Freshness of all unleavened flat bread blends decreased at different periods as well as bread control compared with zero time period. Water holding capacity (WHC) was significantly increased in all samples compared with wheat bread. Supplementation of bread with $15 \%$ beans recorded the highest value in WHC.
\end{abstract}

\section{Keywords}

Unleavened Flat Bread, Beans, Sorghum, Rheological Properties, Chemical Composition, Sensory

\footnotetext{
*Corresponding author.
}

How to cite this paper: Seleem, H.A. and Omran, A.A. (2014) Evaluation Quality of One Layer Flat Bread Supplemented with Beans and Sorghum Baked on Hot Metal Surface. Food and Nutrition Sciences, 5, 2246-2256. 


\section{Characteristics}

\section{Introduction}

Flat bread is as old as civilization. It is eaten with almost every meal in the Middle East, North Africa and Central Asia. Flat breads are often served freshly baked and produced in both the home and bakeries. Flat bread is simple bread made from flattened dough of flour, water, salt, yeast and other optional ingredients. The manufacture of flat bread necessitates special characteristics in flour and dough. Additional (optional) ingredients may be used for processing aids which are essential in particular in the bread-making process, in improving the quality and for fortification of bread to have more nutritive value. Milk, eggs, other cereals, legumes, dates or date syrup, dried fruits, leafy vegetables, cassava, green banana, flaxseed flour, sesame, black seeds, species, meat, and dried or fresh herbs might be added to the formula of the bread [1].

Legumes have been known as "a poor man's meat". They supply protein, complex carbohydrates, fiber and essential vitamins and minerals to the diet, which are low in fat and sodium and contain no cholesterol [2]. Addition of legume and beans to cereal based products could be a good option for increasing the intake of legumes and beans. In addition, legume proteins are rich in lysine and deficient in sulphur containing amino acids, whereas cereal proteins are deficient in lysine, but have adequate amounts of sulphur amino acids. Therefore, the combination of grain with legume proteins would provide better overall essential amino acid balance, helping to overcome the world protein calorie malnutrition problem [3].

Traditional treatments such as soaking, cooking, germinating and fermenting have been used to improve nutritional quality of the legume [4]-[6]. Food processing technologies can contribute the alleviation of micronutrient deficiencies [7] [8]. Process operations that reduce the level of antinutritional factors and that minimize the losses of micronutrients are of interest. Mechanical, thermal or biological processes have the potential to improve the nutrient availability in foods [8].

Sorghum (Sorghum bicolor L. Moench) is the king of cereals and is one of the important food crops in dry lands of tropical Africa, India and China [9]. The nutrient composition of sorghum indicates that it is a good source of energy, proteins, carbohydrates, oils, polyunsaturated fatty acid (PUFA), vitamins and minerals [10][12]. The most common products are leavened and unleavened breads, porridges, boiled grains and steam cooked products such as couscous [13]. A blend of wheat flour and sorghum flour baked products like muffins, bread and cakes can be produced [14].

Compositing wheat flour with locally available cereals and root crops has been reported to be desirable [15]. It also encourages the agricultural sector and focused on the use of composite flour for bread and baked products in many wheat importing countries within the last two and half decades [16] [17].

The objective of this study was designed to replacement of wheat flour with different mixtures such as beans and sorghum flour to produce one layer flat bread and improve the qualities of this type of bread.

\section{Materials and Methods}

\subsection{Materials}

Wheat flour (72\% extraction rate) and baking ingredients were obtained from local markets. White sorghum (Dorado variety) and beans (Nebraska variety) dried samples were obtained from the Agricultural Research Center, Giza, Egypt. Chemicals were of the analytical reagent grade.

\subsubsection{Preparation of Samples}

The beans and sorghum samples were carefully cleaned and freed from broken grains and extraneous matter. Beans were soaked in water for $3 \mathrm{~h}$. At the end of soaking period, the soaked water was discarded. The beans were dried in drying oven at $45^{\circ} \mathrm{C} \pm 5^{\circ} \mathrm{C}$. The dried soaked beans were milled to obtain fine flour ( 315 micron) and kept for flat bread preparation. Sorghum grains were conditioned to $14 \%$ moisture content for $16 \mathrm{~h}$ and milled by using fractionation Laboratory mill (Brabender Duisburg roller mill, Germany) to obtain fine flour (315 micron).

\subsubsection{Dough Rheological Properties}

The dough rheological properties of different wheat dough blends with beans or sorghum (5\%, $10 \%$ and 15\%) 
were examined (after pre-experiments to choose the suitable percentage) with the Brabender Farinograph and Brabender Extensograph according to the constant flour weight procedure [18].

\subsubsection{Flat Bread Preparation}

Flat bread was prepared according to the method described by Shobha et al. [9]. Flat bread was contained three different concentrations of beans or sorghum flour (5\%,10\% and 15\%) as partial replacement for wheat flour ( $72 \%$ extraction rate). Formula consisted of $100 \mathrm{~g}$ of flour, $7 \mathrm{~g}$ corn oil, $1 \mathrm{~g}$ salt and 50 - $54 \mathrm{ml}$ water as mentioned in Table 1. Flour and other ingredients were mixed and then kneaded nicely to make soft dough of uniform consistency. The dough was well kneaded, divided into small balls (50 g), flattened on a hard wooden surface sprinkled with a small quantity of flour. Dough was baked on both sides on a hot pan over low flame, drizzled the griddle with a little oil and cooked slowly for 1 to 2 minutes per side. The prepared breads were then packed in polyethylene bags and stored at $-20^{\circ} \mathrm{C}$ until further analysis (one layer flat bread pictures at different blends were shown in Figure 1).

\begin{tabular}{|c|c|c|c|c|c|c|c|}
\hline Samples & Formula 1 & Formula 2 & Formula 3 & Formula 4 & Formula 5 & Formula 6 & Formula 7 \\
\hline Wheat flour & 100 & 95 & 90 & 85 & 95 & 90 & 85 \\
\hline Beans flour & - & 5 & 10 & 15 & - & - & - \\
\hline Sorghum flour & - & - & - & - & 5 & 10 & 15 \\
\hline Corn oil & 7 & 7 & 7 & 7 & 7 & 7 & 7 \\
\hline Salt & 1 & 1 & 1 & 1 & 1 & 1 & 1 \\
\hline Water & 50 & 52 & 52 & 54 & 50 & 50 & 50 \\
\hline
\end{tabular}

Formula 1: Wheat control, Formula 2: Beans 5\%, Formula 3: Beans 10\%, Formula 4: Beans 15\%, Formula 5: Sorghum flour 5\%, Formula 6: Sorghum flour 10\%, Formula 7: Sorghum flour 15\%.
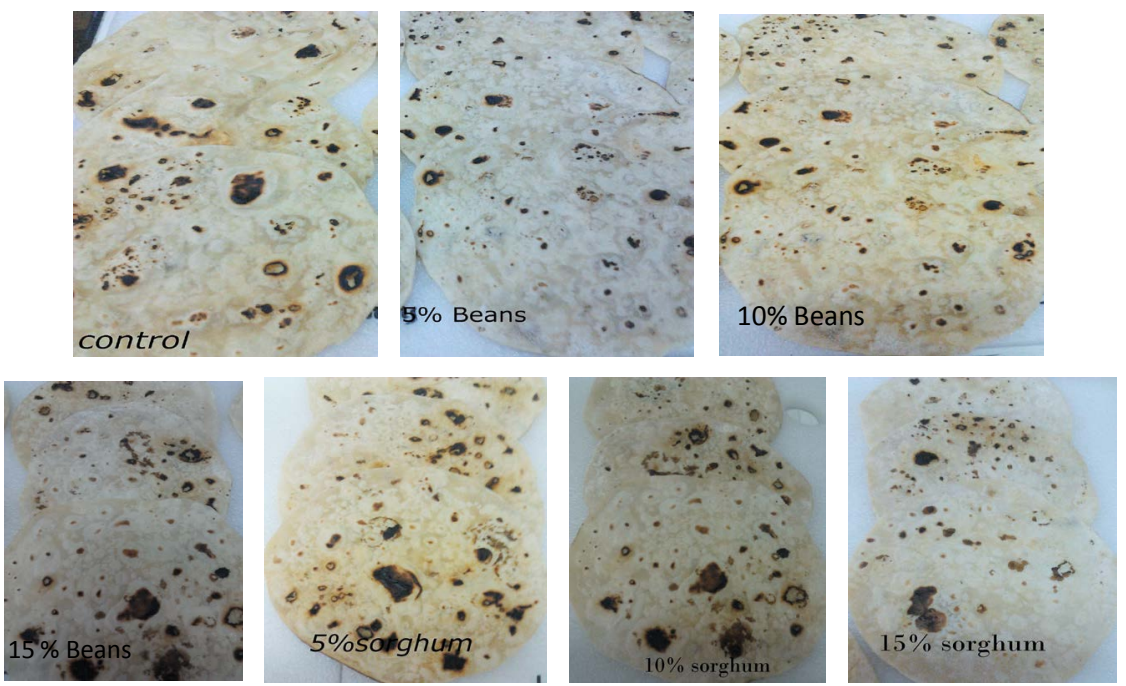

Figure 1. One layer flat bread pictures at different blends.

\subsubsection{Evaluation of Bread}

Bread samples were dried at $45^{\circ} \mathrm{C} \pm 5^{\circ} \mathrm{C}$ and milled for further analysis i.e. staling, functional properties, chemical analysis.

\section{1) Chemical Analysis}

Moisture, protein, fats, crude fiber and ash contents of the raw materials and bread samples were determined according to the methods of AOAC [19]. Total carbohydrate was calculated by difference.

\section{2) Determination of Minerals}


Bread sample (2 g) was weighed and heated at $550^{\circ} \mathrm{C}$. Then the ashes were dissolved with $100 \mathrm{ml} 1 \mathrm{M} \mathrm{HCl}$. Dissolved ash was analyzed for zinc, iron and calcium contents by using methods of AOAC [19]. Perkin Elmer (Model 3300, USA) Atomic Absorption Spectrophotometer was used to determine these minerals.

\section{3) Organoleptic Evaluation of Flat Bread}

Flat bread samples were organolyptically evaluated for its sensory characteristics. Half slice of each bread sample was served for ten panelists on white, odourless and disposable plates. Samples were scored for, taste, chewing ability, texture, aroma and color using a score from 1 to10. The evaluation was carried out according to the method of Land and Shepherd [20].

\section{4) Alkaline Water Retention Capacity during Storage}

Alkaline water retention capacity (AWRC) values of breads were measured after 24, 48 and $72 \mathrm{~h}$ of bread storage at $-20^{\circ} \mathrm{C}$ according to Yamazaki [21] and modified by Kitterman and Rubenthaler [22].

\section{5) Functional Properties of Bread}

Water holding capacity (WHC) was performed according to the method of Beuchat [23]. Two grammas of each milled sample $\left(W_{1}\right)$ were weighed into a pre-weighed centrifuge tube $\left(W_{2}\right)$ and $20 \mathrm{ml}$ of distilled water were added. Samples were vortexed and allowed to stand for $30 \mathrm{~min}$ at $25^{\circ} \mathrm{C} \pm 2^{\circ} \mathrm{C}$ before being centrifuged at $4000 \mathrm{~g}$ for $25 \mathrm{~min}$. Excess water was decanted by inverting the tubes over absorbent paper and samples were allowed to drain and reweighed $\left(W_{3}\right)$. The percentage of water holding capacity were calculated as:

$$
W H C \%=\frac{W_{3}-W_{2}}{W_{1}} \times 100
$$

\subsubsection{Statistic Analysis}

For the analytical data, mean values and standard deviation are reported. The data obtained were subjected to one-way analysis of variance (ANOVA) at $P<0.05$.

\section{Results and Discussion}

\subsection{Dough Rheological Properties}

Table 2 exhibits the rheological properties of dough at different blends. Data in Table 2 showed that water absorption was varied from $57.0 \%$ to $65.60 \%$ of dough at different blends. Differences in water absorption of control, $5 \%, 10 \%$ and $15 \%$ for each beans and sorghum flour due to the different protein contents. Flour that is used for flat bread production has optimum water absorption of varying between $38 \%$ and $85 \%$ [24]. Water is a basic component that helps to get a homogenic mixture of other components in dough, and providing it with a desired viscoelastic structure as well as very effective on final product quality. Water as a dissolving agent for many

Table 2. Farinograph and extensograph of flour with different blends.

\begin{tabular}{|c|c|c|c|c|c|c|c|}
\hline \multirow[t]{2}{*}{ Samples } & \multicolumn{2}{|c|}{ Farinograph } & \multicolumn{4}{|c|}{ Extensograph } & \multirow[b]{2}{*}{$\begin{array}{l}\text { Energy } \\
\left(\mathrm{cm}^{2}\right)\end{array}$} \\
\hline & $\begin{array}{c}\text { Water } \\
\text { absorption (\%) }\end{array}$ & $\begin{array}{l}\text { Stability } \\
\text { (min) }\end{array}$ & $\begin{array}{c}\text { Degree of } \\
\text { softening (B.U) }\end{array}$ & $\begin{array}{c}\text { Elasticity } \\
\text { (B.U) }\end{array}$ & $\begin{array}{c}\text { Extensibility } \\
\text { (mm) }\end{array}$ & $\begin{array}{l}\text { P.N }{ }^{*} \\
\text { ratio }\end{array}$ & \\
\hline Wheat control & $60.50 \pm 0.01^{\mathrm{c}}$ & $1.25 \pm 0.01^{\mathrm{e}}$ & $95.0 \pm 0.01^{\mathrm{b}}$ & $450.0 \pm 0.05^{\mathrm{a}}$ & $110.0 \pm 0.03^{\mathrm{d}}$ & $4.10 \pm 0.01^{\mathrm{a}}$ & $72.0 \pm 0.02^{\mathrm{b}}$ \\
\hline $5 \%$ beans & $60.70 \pm 0.02^{\mathrm{c}}$ & $6.50 \pm 0.01^{\mathrm{a}}$ & $45.0 \pm 0.01^{\mathrm{e}}$ & $390.0 \pm 0.05^{\mathrm{b}}$ & $120.0 \pm 0.01^{\mathrm{c}}$ & $3.25 \pm 0.01^{\mathrm{d}}$ & $80.0 \pm 0.04^{\mathrm{a}}$ \\
\hline $10 \%$ beans & $62.30 \pm 0.01^{\mathrm{b}}$ & $4.50 \pm 0.01^{\mathrm{b}}$ & $45.0 \pm 0.02^{\mathrm{e}}$ & $380.0 \pm 0.02^{\mathrm{c}}$ & $105.0 \pm 0.02^{\mathrm{e}}$ & $3.62 \pm 0.02^{\mathrm{b}}$ & $71 \pm 0.01^{\mathrm{c}}$ \\
\hline $15 \%$ beans & $65.60 \pm 0.05^{\mathrm{a}}$ & $3.50 \pm 0.03^{\mathrm{c}}$ & $60.0 \pm 0.01^{\mathrm{d}}$ & $320.0 \pm 0.02^{\mathrm{d}}$ & $95.0 \pm 0.01^{\mathrm{g}}$ & $3.40 \pm 0.01^{\mathrm{c}}$ & $50.0 .0 \pm 0.02^{\mathrm{f}}$ \\
\hline $5 \%$ sorghum flour & $58.00 \pm 1.01^{\mathrm{d}}$ & $1.50 \pm 0.02^{\mathrm{d}}$ & $45.0 \pm 0.01^{\mathrm{e}}$ & $280.0 \pm 0.01^{\mathrm{e}}$ & $137.0 \pm 0.01^{\mathrm{a}}$ & $1.80 \pm 0.01^{\mathrm{g}}$ & $55.0 \pm 0.01^{\mathrm{d}}$ \\
\hline $10 \%$ sorghum flour & $57.60 \pm 0.02^{\mathrm{de}}$ & $1.00 \pm 0.01^{\mathrm{f}}$ & $90.0 \pm 0.03^{c}$ & $260.0 \pm 0.03^{f}$ & $125.0 \pm 0.02^{\mathrm{b}}$ & $2.20 \pm 0.01^{\mathrm{f}}$ & $52.0 \pm 0.01^{\mathrm{e}}$ \\
\hline $15 \%$ sorghum flour & $57.00 \pm 0.02^{\mathrm{e}}$ & $0.75 \pm 0.01^{\mathrm{g}}$ & $100.0 \pm 0.03^{\mathrm{a}}$ & $240.0 \pm 0.03^{g}$ & $97.0 \pm 0.02^{\mathrm{f}}$ & $2.90 \pm 0.01^{\mathrm{e}}$ & $43.0 \pm 0.01^{\mathrm{g}}$ \\
\hline
\end{tabular}

"P.N = Proportional number. Values are mean of three replicates \pm SD, number in the same column followed by the same letter are not significantly different at 0.05 level. 
organic or inorganic substances is a substance that helps dissolving hydrophilic components such as salt, sugar and insoluble proteins and forms gluten by hydrating in- soluble proteins in water [25].

Results are in agreements with Deshpande et al. [26] and Morales-de-Le'on et al. [27] whom found that water absorption was increased by addition of bean flour as a result of increased rate of substitution. Substituting wheat flour with $15 \%$ bean flour resulted in increases in water absorption of $3 \%-5 \%$. Several studies also reported that the dough made from composite flour absorbed more water than that made from wheat flour alone [28] [29].

Dough stability decreased from 6.50 to $3.50 \mathrm{~min}$ for bean blends and from 1.50 to $0.75 \mathrm{~min}$ for sorghum blends as the same as increasing addition. Deshpande et al. [26] found that dough stability decreased abruptly as bean flour was added. This is logical since beans are absent of proteins that give wheat dough its viscoelastic properties.

Softening gradually increased with increasing the levels of addition from 45 to 60 B.U for bean blends and from 45 to 100 B.U for sorghum blends. Addition of 15\% sorghum had the highest degree of softening compared with wheat control and beans mixtures.

From Table 2, it could be noticed that addition of beans or sorghum to wheat flour at different levels decreased the extensibility, elasticity and the energy of produced dough and the reduction was increased with increasing the level of substitution. In contrast, addition of beans or sorghum to wheat flour increased the proportional number (P.N) of dough of the produced dough from 3.25 to 3.62 and from 1.80 to 2.90 for beans and sorghum dough, respectively.

The water absorption and extensibility of wheat dough decreased on addition of sorghum flour and it also resulted in lesser loaf volume and weight of bread [30]. The addition of wheat flour to sorghum flour improved the dough rheological properties [31] [32]. Processing of sorghum flour into products has faced several limitations. Sorghum, being a gluten-free cereal behaves quite differently from wheat and has poor rheological properties in terms of its pliability, and extensibility [33] [34].

\subsection{Chemical Composition}

Chemical composition of raw materials was shown in Table 3. Wheat flour contains 11.21 protein, 0.70 ash, 0.44 crude fiber, 1.26 fats and $86.82 \%$ total carbohydrate. Sorghum flour contains 10.72 protein, 1.81 ash, 2.04 crude fiber, 1.40 fats and $86.07 \%$ total carbohydrate. Whereas bean flour contains 23.71 protein, 4.00 ash, 4.43 crude fiber, 1.30 fats and $70.99 \%$ total carbohydrate. The chemical composition is close to Malomo et al. [35]; Manay Shakuntalan and Shabakshanaswamy [36] and Wani et al. [37] who have reported the chemical composite of wheat, beans and sorghum, respectively.

Table 4 presents chemical composition of unleavened flat bread at different blends. Protein content varied from $9.88 \%$ to $10.18 \%$ and $9.07 \%$ to $9.24 \%$ for beans, and sorghum bread, respectively. Protein was significantly higher in bread fortified with beans then sorghum. Legume proteins are rich source of lysine [38]. Therefore, supplementation of sorghum with legumes has been advocated as a way of combating Protein-calorie Malnutrition. Wheat, rice sorghum and legumes were recommended as good ingredients for production of cereal-based baby foods [39].

The addition of bean flour to wheat flour was expected to increase the protein content of the final product, since legumes generally contain more proteins than cereals [40]. Addition of legume flour on wheat flour baked products improves the essential amino acid balance of such foods [40]-[43].

Table 3. Chemical composition of raw materials (\% on dwt)*.

\begin{tabular}{cccccc}
\hline Samples & Protein & Crude fiber & Fats & Ash & TC \\
\hline Wheat flour & $11.21 \pm 0.01^{\mathrm{b}}$ & $0.44 \pm 0.01^{\mathrm{c}}$ & $1.26 \pm 0.03^{\mathrm{b}}$ & $0.70 \pm 0.01^{\mathrm{c}}$ & $86.82 \pm 0.04^{\mathrm{a}}$ \\
Sorghum flour & $10.72 \pm 0.02^{\mathrm{b}}$ & $2.04 \pm 0.01^{\mathrm{b}}$ & $1.40 \pm 0.02^{\mathrm{a}}$ & $1.81 \pm 0.01^{\mathrm{b}}$ & $86.07 \pm 0.05^{\mathrm{a}}$ \\
Beans flour & $23.71 \pm 0.73^{\mathrm{a}}$ & $4.43 \pm 0.02^{\mathrm{a}}$ & $1.30 \pm 0.01^{\mathrm{b}}$ & $4.00 \pm 0.02^{\mathrm{a}}$ & $70.99 \pm 0.71^{\mathrm{b}}$ \\
\hline
\end{tabular}

"dwt basis = dry weight basis. ${ }^{* *}$ TC $=$ Total carbohydrate was calculated by difference. Values are mean of three replicates $\pm \mathrm{SD}$, number in the same column followed by the same letter are not significantly different at 0.05 level. 
Table 4. Chemical composition and minerals of flat bread with different blends (on dwt).

\begin{tabular}{|c|c|c|c|c|c|c|c|c|}
\hline Bread samples & $\begin{array}{l}\text { Protein } \\
(\%)\end{array}$ & $\begin{array}{c}\text { Crude fiber } \\
\text { (\%) }\end{array}$ & $\begin{array}{l}\text { Fats } \\
(\%)\end{array}$ & $\begin{array}{l}\text { Ash } \\
\text { (\%) }\end{array}$ & $\begin{array}{l}\text { TC } \\
(\%)\end{array}$ & $\begin{array}{c}F e \\
(\mathrm{mg} / 100 \mathrm{~g})\end{array}$ & $\begin{array}{c}\mathrm{Ca} \\
(\mathrm{mg} / \mathbf{1 0 0 g})\end{array}$ & $\underset{(\mathrm{mg} / \mathbf{1 0 0 g})}{\mathrm{Zn}}$ \\
\hline Wheat flour (control) & $9.26 \pm 0.17^{c}$ & $0.40 \pm 0.02^{\mathrm{e}}$ & $2.84 \pm 0.01^{\mathrm{f}}$ & $1.60 \pm 0.07^{\mathrm{e}}$ & $86.29 \pm 0.18^{\mathrm{a}}$ & $6.03 \pm 0.92^{\mathrm{b}}$ & $15.30 \pm 0.05^{\mathrm{d}}$ & 0.96 \\
\hline $5 \%$ beans & $9.88 \pm 0.10^{\mathrm{b}}$ & $0.51 \pm 0.01^{\mathrm{cd}}$ & $3.17 \pm 0.02^{\mathrm{e}}$ & $1.90 \pm 0.02^{\mathrm{c}}$ & $85.05 \pm 0.14^{\mathrm{d}}$ & $6.68 \pm 0.01^{\mathrm{ab}}$ & $19.40 \pm 0.02^{\mathrm{b}}$ & 1.01 \\
\hline $10 \%$ beans & $9.96 \pm 0.04^{\mathrm{b}}$ & $0.62 \pm 0.02^{\mathrm{b}}$ & $3.26 \pm 0.06^{\mathrm{d}}$ & $2.00 \pm 0.02^{\mathrm{b}}$ & $84.78 \pm 0.12^{\mathrm{e}}$ & $7.06 \pm 0.20^{\mathrm{a}}$ & $18.66 \pm 0.02^{\mathrm{C}}$ & $1.04 \pm 0.01^{\text {bcd }}$ \\
\hline $15 \%$ beans & $10.18 \pm 0.02^{\mathrm{a}}$ & $0.79 \pm 0.01^{\mathrm{a}}$ & $3.34 \pm 0.02^{c}$ & $2.10 \pm 0.01^{\mathrm{a}}$ & $84.38 \pm 0.05^{\mathrm{f}}$ & $7.11 \pm 0.43^{\mathrm{a}}$ & $21.56 \pm 0.05^{\mathrm{a}}$ & $1.12 \pm 0.02^{\mathrm{ab}}$ \\
\hline $5 \%$ sorghum flour & $9.07 \pm 0.13^{\mathrm{d}}$ & $0.43 \pm 0.01^{\mathrm{e}}$ & $3.40 \pm 0.05^{\mathrm{c}}$ & $1.61 \pm 0.02^{\mathrm{e}}$ & $85.94 \pm 0.20^{\mathrm{b}}$ & $7.50 \pm 0.05^{\mathrm{a}}$ & $13.45 \pm 0.05^{\mathrm{e}}$ & $1.02 \pm 0.01^{\mathrm{cd}}$ \\
\hline $10 \%$ sorghum flour & $9.13 \pm .03^{\mathrm{cd}}$ & $0.48 \pm 0.02^{\mathrm{d}}$ & $3.50 \pm 0.05^{\mathrm{b}}$ & $1.63 \pm 0.03^{\mathrm{e}}$ & $85.74 \pm 0.13^{\mathrm{b}}$ & $7.17 \pm 0.51^{\mathrm{a}}$ & $13.01 \pm 0.01^{\mathrm{g}}$ & $1.07 \pm 0.01^{\mathrm{abc}}$ \\
\hline $15 \%$ sorghum flour & $9.24 \pm 0.03^{c}$ & $0.53 \pm 0.03^{\mathrm{c}}$ & $3.57 \pm 0.02^{\mathrm{a}}$ & $1.70 \pm 0.01^{\mathrm{d}}$ & $85.49 \pm 0.06^{c}$ & $7.18 \pm 0.21^{\mathrm{a}}$ & $13.22 \pm 0.02^{f}$ & $1.15 \pm 0.08^{\mathrm{a}}$ \\
\hline
\end{tabular}

*dwt basis = dry weight basis. ${ }^{* *} \mathrm{TC}=$ Total carbohydrate was calculated by difference. Values are mean of three replicates \pm SD, number in the same column followed by the same letter are not significantly different at 0.05 level.

Bread supplemented with beans had the highest values in protein, ash and fiber compared with wheat and sorghum bread.

Fats content of unleavened flat bread at different blends was shown in Table 4. Fat content ranged from 3.17 to $3.34 \%$ and from $3.40 \%$ to $3.57 \%$ in beans and sorghum bread, respectively. Bread supplemented with sorghum had the highest values in fat content compared with wheat and beans bread.

\subsection{Minerals Content}

Table 4 shows minerals content i.e., calcium (Ca), iron (Fe) and zinc ( $\mathrm{Zn})$ of unleavened flat bread at different blends. Results indicated that the Fe values of beans and sorghum bread varied from 6.68 to $7.11 \mathrm{mg} / 100 \mathrm{~g}$ and from 7.17 to $7.50 \mathrm{mg} / 100 \mathrm{~g}$, respectively. Bread supplemented with sorghum flour had the highest Fe and $\mathrm{Zn}$ content compared with beans and wheat bread and the increase was gradually with increasing the addition of sorghum.

From Table 4, it could be noticed that the Ca content was significantly difference in different blends. In general, Ca was higher in beans bread, while it was lower in sorghum and wheat bread. Minerals are vital to the functioning of many body processes. They are critical players in the functioning of the nervous system, other cellular processes, water balance and structural (e.g. skeletal) systems [44]. Inadequate intakes of micronutrients (minerals) have been associated with severe malnutrition, increased disease conditions and mental impairment [45] [46]. Breads contain zinc ranged from 0.77 to $2.0 \mathrm{mg} / 100 \mathrm{~g}$ [47].

\subsection{Organoleptic Characteristics}

One of the limiting factors for consumer acceptability is the organoleptic properties therefore; taste, chewing ability, texture, aroma and color were performed. Flat bread was prepared with replacement wheat flour (72\% ext.) by $5 \%, 10 \%$ and $15 \%$ bean or sorghum flour. Results in Table 5 showed that bread produced from beans or sorghum flour had acceptable values of taste comparing with wheat control bread except for addition of 10\% and $15 \%$ sorghum flour. Chewing ability, texture and aroma scores were non significantly differences compared with wheat control bread. There is a non significant difference between different blends in color compared with wheat control bread except for addition of $10 \%$ and $15 \%$ sorghum flour. Moreover, colors of beans bread were very close to those in wheat control bread.

The appearance of the bread fortified with $20 \%$ soyabean flour with sorghum was superior for texture. The mean comparison of scores of different attributes like texture, flavor, taste, appearance, mouth feel and overall acceptability were recorded and found to be non significant differences with the treatment groups [14]. Flat bread may be prepared from wheat flour with an addition of chickpea, pigeon pea and bean flours to improve the nutritive value, textural and organoleptic properties. Protein efficiency ratio (PER) of supplemented breads was significantly increased. Enrichment of Egyptian balady bread with decorticated cracked broad bean flour (Vicia faba) increases the essential amino acids and the PER was found to be significantly greater [48]. Improvements 
Table 5. Sensory evaluation of flat bread with different blends.

\begin{tabular}{cccccc}
\hline Bread samples & Taste (10) & Chewing ability (10) & Texture (10) & Aroma (10) & Color (10) \\
\hline Wheat flour (control) & $8.70 \pm 0.67^{\mathrm{a}}$ & $8.65 \pm 0.75^{\mathrm{a}}$ & $8.88 \pm 0.92^{\mathrm{a}}$ & $9.10 \pm 0.74^{\mathrm{a}}$ & $8.95 \pm 1.19^{\mathrm{a}}$ \\
5\% beans & $8.20 \pm 1.23^{\mathrm{ab}}$ & $8.35 \pm 1.37^{\mathrm{a}}$ & $8.10 \pm 1.17^{\mathrm{a}}$ & $8.70 \pm 1.64^{\mathrm{a}}$ & $9.00 \pm 1.25^{\mathrm{a}}$ \\
10\% beans & $8.50 \pm 0.69^{\mathrm{ab}}$ & $8.40 \pm 0.52^{\mathrm{a}}$ & $8.65 \pm 0.67^{\mathrm{a}}$ & $8.80 \pm 0.79^{\mathrm{a}}$ & $8.85 \pm 0.88^{\mathrm{a}}$ \\
$15 \%$ beans & $8.15 \pm 0.75^{\mathrm{ab}}$ & $8.15 \pm 1.00^{\mathrm{a}}$ & $8.40 \pm 1.26^{\mathrm{a}}$ & $8.30 \pm 0.95^{\mathrm{a}}$ & $8.70 \pm 0.79^{\mathrm{ab}}$ \\
$5 \%$ sorghum flour & $7.75 \pm 0.48^{\mathrm{ab}}$ & $8.55 \pm 0.70^{\mathrm{a}}$ & $9.00 \pm 0.52^{\mathrm{a}}$ & $8.80 \pm 1.03^{\mathrm{a}}$ & $8.25 \pm 0.98^{\mathrm{ab}}$ \\
$10 \%$ sorghum flour & $7.30 \pm 1.34^{\mathrm{b}}$ & $8.20 \pm 1.14^{\mathrm{a}}$ & $8.55 \pm 1.53^{\mathrm{a}}$ & $8.40 \pm 1.43^{\mathrm{a}}$ & $7.80 \pm 1.03^{\mathrm{b}}$ \\
$15 \%$ sorghum flour & $7.45 \pm 1.28^{\mathrm{b}}$ & $8.10 \pm 1.10^{\mathrm{a}}$ & $8.55 \pm 1.28^{\mathrm{a}}$ & $8.40 \pm 1.60^{\mathrm{a}}$ & $7.75 \pm 1.09^{\mathrm{b}}$ \\
\hline
\end{tabular}

Values are mean of ten replicates \pm SD, number in the same column followed by the same letter are not significantly different at 0.05 level.

of flat bread quality and keeping quality are essential. Automation of flat bread making must be increased [1].

\subsection{Alkaline Water Retention Capacity during Storage}

Alkalin water retention capacity (AWRC) of the flat bread was taken as indication on staling degree and freshness. It was determined at different periods; zero time and after storage periods (24, 48 and $72 \mathrm{~h}$ ) as shown in Table 6. From results, it could be noticed that alkalin water retention capacity of beans and sorghum bread at zero time was lower than wheat bread (280.46\% - 287.30\% and $250.51 \%-263.24 \%$, respectively). Freshness of all flat bread blends was decreased at different periods as well as bread control compared with zero time period. Shaikh et al. [49] found that the rate of bread staling at refrigerated temperature is less as compared to that at $\left(29^{\circ} \mathrm{C} \pm 1^{\circ} \mathrm{C}\right)$ storage. Freshly baked flat breads are soft and elastic. When kept at room temperature they stale within few hours and become hard and tough. For example; chapatis are generally prepared twice a day for lunch and dinner, and unless eaten immediately after preparation, they stale rapidly and become difficult to chew [50]. The staling of large scale manufactured chapatis may become a critical factor consideration [51].

Table 6. Alkaline water retention capacity during storage of flat bread with different blends (\%).

\begin{tabular}{|c|c|c|c|c|}
\hline \multirow{2}{*}{ Bread samples } & \multicolumn{4}{|c|}{ Storage periods (h) } \\
\hline & Zero time & $24 \mathrm{~h}$ & $48 \mathrm{~h}$ & $72 \mathrm{~h}$ \\
\hline Wheat flour (control) & $288.87 \pm 1.93^{\mathrm{a}}$ & $263.57 \pm 3.03^{b}$ & $243.55 \pm 2.47^{\mathrm{b}}$ & $211.51 \pm 0.40^{f}$ \\
\hline $5 \%$ beans & $287.30 \pm 1.83^{\mathrm{a}}$ & $257.51 \pm 1.28^{\mathrm{d}}$ & $229.05 \pm 3.62^{\mathrm{c}}$ & $196.26 \pm 0.10^{\mathrm{g}}$ \\
\hline $10 \%$ beans & $281.65 \pm 0.20^{\mathrm{b}}$ & $260.67 \pm 0.52^{c}$ & $250.80 \pm 0.87^{\mathrm{a}}$ & $227.50 \pm 1.75^{\mathrm{b}}$ \\
\hline $15 \%$ beans & $280.46 \pm 0.45^{\mathrm{b}}$ & $271.89 \pm 0.10^{\mathrm{a}}$ & $254.14 \pm 3.03^{\mathrm{a}}$ & $242.96 \pm 0.20^{\mathrm{a}}$ \\
\hline $5 \%$ sorghum flour & $263.24 \pm 0.20^{c}$ & $253.42 \pm 0.30^{\mathrm{e}}$ & $241.67 \pm 0.52^{b}$ & $223.78 \pm 0.10^{d}$ \\
\hline $10 \%$ sorghum flour & $256.52 \pm 0.30^{d}$ & $234.89 \pm 0.20^{\mathrm{g}}$ & $229.68 \pm 0.30^{c}$ & $225.34 \pm 0.33^{c}$ \\
\hline $15 \%$ sorghum flour & $250.51 \pm 0.28^{\mathrm{e}}$ & $244.63 \pm 0.40^{\mathrm{f}}$ & $223.01 \pm 1.08^{\mathrm{d}}$ & $219.53 \pm 0.50^{\mathrm{e}}$ \\
\hline
\end{tabular}

Values are mean of three replicates $\pm \mathrm{SD}$, number in the same column followed by the same letter are not significantly different at 0.05 level.

\subsection{Water Holding Capacity}

Table 7 exhibits water holding capacity (WHC) of unleavened flat bread at different blends. Data showed that WHC ranged from $223.33 \%$ to $233.43 \%$ and $218.77 \%$ to $223.18 \%$ for beans and sorghum bread, respectively. WHC were significantly increased in all samples compared with wheat bread (control). Supplementation of bread with $15 \%$ beans recorded the highest value in WHC. Sultan [52] reported that the water absorption is due to increase in quality of flour mixture which also ensures the retention of moisture during dough processing for baked products. Vegetable fibers show practical properties including water holding capacity, swell capacity, 
Table 7. Water holding capacity (WHC) of flat bread with different blends (\%)*

\begin{tabular}{cc}
\hline Bread samples & WHC \\
\hline Wheat flour (control) & $212.83 \pm 2.00^{\mathrm{e}}$ \\
$5 \%$ beans & $223.33 \pm 3.00^{\mathrm{c}}$ \\
$10 \%$ beans & $228.85 \pm 3.26^{\mathrm{b}}$ \\
$15 \%$ beans & $233.43 \pm 0.40^{\mathrm{a}}$ \\
$5 \%$ sorghum flour & $218.77 \pm 0.85^{\mathrm{d}}$ \\
$10 \%$ sorghum flour & $220.11 \pm 0.10^{\text {cd }}$ \\
$15 \%$ sorghum flour & $223.18 \pm 3.45^{\mathrm{c}}$ \\
\hline
\end{tabular}

*WHC = water holding capacity. Values are mean of three replicates \pm SD, number in the same column followed by the same letter are not significantly different at 0.05 level.

increased viscosity or gelation, ability to bond to biliary acids and cationic exchange capacity which all have significant role in physiological functions [53]. These are due to their porous network structure formed by polysaccharide chains which may hold high amount of water through hydrogen bond [54], or water may be hold in capillary structures of fibers through surface absorption [55].

\section{Conclusion}

From results it could be concluded that protein affected dough rheological parameters and bread staling. Bread supplemented with beans had the highest values in protein, ash, fiber and Ca compared with wheat and sorghum bread. Bread supplemented with sorghum had the highest values in fat, Fe and $\mathrm{Zn}$ content. Bread produced from beans or sorghum flour had acceptable sensory properties. Freshness of all flat bread blends was decreased at different periods as well as bread control compared with zero time period. WHC was significantly increased in all samples compared with wheat bread. Supplementation of bread with $15 \%$ beans recorded the highest value in WHC. The most suitable addition was the beans addition. Substitution of wheat flour with $15 \%$ beans flour could be considered the best addition because all the sensory quality characteristics of the breads were the same as control. Bean is the reasonable source of quality protein available from the household food stuffs.

\section{Acknowledgements}

Authors would like to thank the Food Technology Research Institute, Agricultural Research Center for ongoing collaboration to support research and that provided facilities necessary to accomplish the desired goals of research.

\section{References}

[1] Al-Dmoor, H.M. (2012) Flat Bread: Ingredients and Fortification. Quality Assurance and Safety of Crops and Foods, 4, 2-8. http://dx.doi.org/10.1111/j.1757-837X.2011.00121.x

[2] Bornet, F.R., Billaux, M.S. and Messing, B. (1997) Glycaemic Index Concept and Metabolic Diseases. International Journal of Biological Macromolecules, 21, 207-219. http://dx.doi.org/10.1016/S0141-8130(97)00066-4

[3] Livingstone, A.S., Feng, J.J. and Malleshi, N.G. (1993) Development and Nutritional Quality Evaluation of Weaning Foods Based on Malted, Popped and Dried Wheat and Chickpea. International Journal of Food Science Technology, 28, 35-43. http://dx.doi.org/10.1111/j.1365-2621.1993.tb01249.x

[4] Hahn, D.H. and Rooney, L.W. (1985) Effect of Genotype on Tannin and Phenols of Sorghum. Cereal Chemistry, 63, 4-8.

[5] Egli, I., Davidsson, L., Juillerat, M.A., Barclay, D. and Hurrell, R.F. (2002) The Influence of Soaking and Germination on the Phytase Activity and Phytic Acid Content of Grains and Seeds Potentially Useful for Complementary Feeding. Journal of Food Science, 67, 3484-3488. http://dx.doi.org/10.1111/j.1365-2621.2002.tb09609.x

[6] Steiner, T., Mosenthin, R., Zimmermann, B., Greiner, R. and Roth, S. (2007) Distribution of Total Phosphorus, Phytate 
Phosphorus and Phytase Activity in Legume Seeds, Cereals and Cereal By-Products as Influenced by Harvest Year and Cultivar. Animal Feed Science and Technology, 133, 320-334.

http://dx.doi.org/10.1016/j.anifeedsci.2006.04.007

[7] Traoré, T., Mouquet, C., Icard-Verniere, C., Traore, A.S. and Treche, S. (2004) Changes in Nutrient Composition, Phytate and Cyanide Contents and $\alpha$-Amylase Activity during Cereal Malting in Small Production Units in Ouagadougou (Burkina Faso). Food Chemistry, 88, 105-114. http://dx.doi.org/10.1016/j.foodchem.2004.01.032

[8] Kayodé, A.P.P. (2006) Diversity, Users’ Perception and Food Processing of Sorghum: Implications for Dietary Iron and Zinc Supply. Ph.D. Dissertation, Wageningen University, Wageningen, 151.

[9] Shobha, V., Kasturiba, B., Naik, R. K. and Yenagi, N. (2008) Nutritive Value and Quality Characteristics of Sorghum Genotypes. Karnataka Journal of Agriculture Science, 20, 586-588.

[10] Dicko, M.H., Gruppen, H., Traoré, A.S., Voragen, A.G.J. and van Berkel, W.J.H. (2006) Sorghum Grain as Human Food in Africa: Relevance of Content of Starch and Amylase Activities. African Journal of Biotechnology, 5, 384-395.

[11] Afify, A.M.R., El-Beltagi, H.S., Abd El-Salam, S.M. and Omran, A.A. (2012) Protein Solubility, Digestibility and Fractionation after Germination of Sorghum Varieties. PLOS ONE, 7, e31154. http://dx.doi.org/10.1371/journal.pone.0031154

[12] Afify, A.M.R., El-Beltagi, H.S., Abd El-Salam, S.M. and Omran, A.A. (2012) Effect of Soaking, Cooking, Germination and Fermentation Processing on Proximate Analysis and Mineral Content of Three White Sorghum Varieties (Sorghum bicolor L. Moench). Notulae Botanicae Horti Agrobotanici Cluj-Napoca, 40, 92-98.

[13] Prasada Rao, K.E. and Murty, D.S. (1981) Sorghum for Special Uses. Proceedings of the International Symposium on Sorghum Grain Quality, Patancheru, 129-134.

[14] Dhore, K.R. (2011) Sensory Evaluation of Sorghum Chakali Enriched with Different Levels of Soyabean Flours. International Referred Research Journal, 3, 50-51.

[15] Oyarekua, M.A. and Adeyeye, E.I. (2009) Comparative Evaluation of the Nutritional Quality, Functional Properties and Amino Acid Profile of Co-Fermented Maize/Cowpea and Sorghum/Cowpea Ogi as Infant Complementary Food. Asian Journal of Clinical Nutrition, 1, 31-39. http://dx.doi.org/10.3923/ajcn.2009.31.39

[16] Mepba, H.D., Eboh, L. and Nwaojigwa, S.U. (2005) Chemical Composition, Functional and Baking Properties of Wheat-Plantain Composite Flours. African Journal of Food, Agriculture, Nutrition and Development, 7, 1-22.

[17] Mohammed, M.A.E., Makki, H.M.M. and Mustafa, A.E.M.I. (2011) Production of Cereal-Based Infant Food from Sorghum [Sorghum bicolor (L) Moench] and Pigeon Pea (Cajanus cajan). Pakistan Journal of Nutrition, 10, 910-913. http://dx.doi.org/10.3923/pjn.2011.910.913

[18] AACC, American Association of Cereal Chemists (2002) Approved Methods of the AACC. 8th Edition, American Association Cereal Chemistry. Method 54-21, St. Paul.

[19] AOAC (2005) Official Methods of Analysis of the Association of Official Analytical Chemists. 18th Edition, Washington DC.

[20] Land, D.G. and Shepherd, R. (1988) Scaling and Ranking Methods. In: Piggott, J.R., Ed., Sensory Analysis of Foods, Elsevier Applied Science, London, 155-185.

[21] Yamazaki, W.T. (1953) An Alkaline Water Retention Capacity Test for the Evaluation of Cookie Baking Potentialities of Soft Winter Wheat Flours. Cereal Chemistry, 30, 242-246.

[22] Kitterman, J.S. and Rubenthaler, G.L. (1971) Assessing the Quality of Early Generation Wheat Selection with the Micro AWRC Test. Cereal Science Today, 16, 313-316.

[23] Beuchat, L.R. (1977) Functional and Electrophoretic Characteristics of Succinylated Peanut Flour Protein. Journal of Agricultural and Food Chemistry, 25, 258-261. http://dx.doi.org/10.1021/jf60210a044

[24] Coskuner, Y., Karababa, E. and Ercan, R. (1999) Flat Bread Production Technology. The Journal of Food, $24,83-97$.

[25] Elgun, A. and Ertugay, Z. (1995) Cereals Processing Technology. Ataturk University Press, Erzurum, 376 p.

[26] Deshpande, S.S., Rangnekar, P.D., Sathe, S.K. and Salunkhe, D.K. (1983) Functional Properties of Wheat-Bean Composite Flours. Journal of Food Science, 48, 1659-1662. http://dx.doi.org/10.1111/j.1365-2621.1983.tb05054.x

[27] Morales-de-León, J.C., Vázquez-Mata, N., Torres, N., Gil-Zenteno, L. and Brezan, R. (2007) Preparation and Characterization of Protein Isolate Fresh and Hardened Beans (Phaseolus vulgaris L.). Journal of Food Science, 72, C96C102. http://dx.doi.org/10.1111/j.1750-3841.2006.00244.X

[28] Lee, M.R., Swanson, B.G. and Baik, B.K. (2001) Influence of Amylose Content on Properties of Wheat Starch and Bread Making Qualities of Starch and Gluten Blends. Cereal Chemistry, 78, 701-706. http://dx.doi.org/10.1094/CCHEM.2001.78.6.701 
[29] Morita, N., Maeda, T., Miyazaki, M., Yamamori, M., Miura, H. and Ohtsuka, I. (2002) Dough and Baking Properties of High Amylase and Waxy Wheat Flours. Cereal Chemistry, 79, 491-495. http://dx.doi.org/10.1094/CCHEM.2002.79.4.491

[30] Hussein, M.A., Saleh, A. and Noaman, M. (1977) Effect of Adding Sorghum Flour on Physical and Chemical Properties of Bread. Periodica Polytechnica-Chemical Engineering, 21, 343-354.

[31] Foda, Y.H., Ramy, A., Rasmy, N.M., Abu-Salem, F.M.A. and Yassen, A.A.E. (1987) Rheological and Sensory Characteristics of Doughs and Balady Bread Based on Wheat, Sorghum, Millet and Defatted Soy Flours. Annals of Agricultural Science, Ain Shams University, 32, 381-395.

[32] Rao, S.J. and Rao, G.V. (1997) Effect of Incorporation of Sorghum Flour to Wheat Flour on Chemical, Rheological and Bread Characteristics. Journal of Food Science and Technology, 34, 251-254.

[33] Bushuk, W. (1985) Rheology: Theory and Application to Wheat Flour Dough. In: Faridi, H., Ed., Rheology of Wheat Products, American Association of Cereal Chemists, Inc., St Paul, 1-26.

[34] Hamann, D.D. and Macdonald, G.A. (1992) Rheology and Texture Properties of Surimi Based Food. In: Lanier, T.C. and Lee, C.M., Eds., Surimi Technology, Marcel Dekker, New York, 429-500.

[35] Malomo, S.A., Eleyinmi, A.F. and Fashakin, J.B. (2011) Chemical Composition, Rheological Properties and Bread Making Potentials of Composite Flours from Breadfruit, Breadnut and Wheat. African Journal of Food Science, 5, 400 -410 .

[36] Manay Shakuntala, N. and Shabakshanaswamy, M. (1997) Chemical Composition of Sorghum Food Facts and Principles. New Age International Publishers, Delhi, 243-245.

[37] Wani, I.A., Sogi, D.S., Wani, A.A. and Gill, B.S. (2013) Physico-Chemical and Functional Properties of Flours from Indian Kidney Bean (Phaseolus vulgaris L.) Cultivars. LWT-Food Science and Technology, 53, 278-284. http://dx.doi.org/10.1016/j.lwt.2013.02.006

[38] Singh, U. (1991) The Role of Pigeon Pea in Human Nutrition. ICRISAT Conference Paper No. CP628, ICRISAT Centre, Patancheru.

[39] Food and Agriculture Organization (FAO) (1979) Human Nutrition in Tropical Africa. Food and Agriculture Organization of the United Nations, Rome.

[40] Tharanathan, R.N. and Mahadevamma, S. (2003) Grain Legumes-A Boon to Human Nutrition. Trends in Food Science and Technology, 14, 507-518. http://dx.doi.org/10.1016/j.tifs.2003.07.002

[41] Koehler, H.H., Chang, C., Scheier, G. and Burke, D.W. (1987) Nutrient Composition, Protein Quality, and Sensory Properties of Thirty-Six Cultivars of Dry Beans (Phaseolus vulgaris L.). Journal of Food Science, 52, 1335-1340. http://dx.doi.org/10.1111/j.1365-2621.1987.tb14076.x

[42] Shehata, N.A., Darwish, N., El-Nahry, F. and Razek, F.A.A. (1988) Supplementation of Wheat Flour with Some Local Legumes. Food/Nahrung, 32, 1-8. http://dx.doi.org/10.1002/food.19880320102

[43] Anton, A.A., Ross, K.A., Lukow, O.M., Gary Fulcher, R. and Arntfield, S.D. (2008) Influence of Added Bean Flour (Phaseolus vulgaris L.) on Some Physical and Nutritional Properties of Wheat Flour Tortillas. Food Chemistry, 109, 33-41. http://dx.doi.org/10.1016/j.foodchem.2007.12.005

[44] Ameh, M.O., Gernah, D.I. and Igbabul, B.D. (2013) Physico-Chemical and Sensory Evaluation of Wheat Bread Supplemented with Stabilized Undefatted Rice Bran. Food and Nutrition Sciences, 4, 43-48. http://dx.doi.org/10.4236/fns.2013.49A2007

[45] Shubhangini, A.J. (2002) Nutrition and Dietetics. 2nd Edition, Tata McGraw-Hill Publishing Co. Ltd., New Delhi.

[46] Abulude, F.O. (2005) Distribution of Selected Minerals in Some Nigerian White Bread. Nigerian Food Journal, 23, 139-147.

[47] Al-Mussali, M.S. and Al-Gahri, M.A. (2009) Nutritive Value of Commonly Consumed Bread in Yemen. E-Journal of Chemistry, 6, 437-444. http://dx.doi.org/10.1155/2009/975960

[48] Abdel-Kader, Z.M. (2001) Enrichment of Egyptian Balady Bread. Part 2. Nutritional Values and Biological Evaluation of Enrichment with Decorticated Cracked Broad Beans Flour (Vicia faba L.). Molecular Nutrition and Food Research, 45, 31-34.

[49] Shaikh, I.M., Ghodke, S.K. and Ananthanarayan, L. (2008) Inhibition of Staling in Chapatti (Indian Unleavened Flat Bread). Journal of Food Processing and Preservation, 32, 378-403. http://dx.doi.org/10.1111/j.1745-4549.2008.00185.x

[50] Shalini, K.G. and Laxmi, A. (2007) Influence of Additives on Rheological Characteristics of Whole-Wheat Dough and Quality of Chapatti (Indian Unleavened Flat Bread) Part I-Hydrocolloids. Food Hydrocolloids, 21, 110-117. http://dx.doi.org/10.1016/j.foodhyd.2006.03.002 
[51] Shaikh, I.M., Shalini, K.G. and Ananthanarayan, L. (2007) Staling of Chapatti (Indian Unleavened Flat Bread). Food Chemistry, 101, 113-119. http://dx.doi.org/10.1016/j.foodchem.2006.01.015

[52] Sultan, W.J. (1990) Practical Baking. 5th Edition, Van Nostrand Reinhold, New York.

[53] Gallaher, D. and Schneeman, B.O. (2001) Dietary Fiber. In: Bowman, B. and Russel, R., Eds., Present Knowledge in Nutrition, ILSI, Washington DC, 805.

[54] Kethireddipalli, P., Hung, Y.C., Phillips, R.D. and Mcwaters, K.H. (2002) Evaluating the Role of Cell Material and Soluble Protein in the Functionality. Journal of Food Science, 67, 53-59. http://dx.doi.org/10.1111/j.1365-2621.2002.tb11358.x

[55] Lopez, G., Ros, G., Rincon, F., Periago, M.J., Martinez, M.C. and Ortuno, J. (1996) Relationship between Physical and Hydration Properties of Soluble and Insoluble Fiber of Artichoke. Journal of Agricultural and Food Chemistry, 44, 2773-2778. 
Scientific Research Publishing (SCIRP) is one of the largest Open Access journal publishers. It is currently publishing more than 200 open access, online, peer-reviewed journals covering a wide range of academic disciplines. SCIRP serves the worldwide academic communities and contributes to the progress and application of science with its publication.

Other selected journals from SCIRP are listed as below. Submit your manuscript to us via either submit@scirp.org or Online Submission Portal.
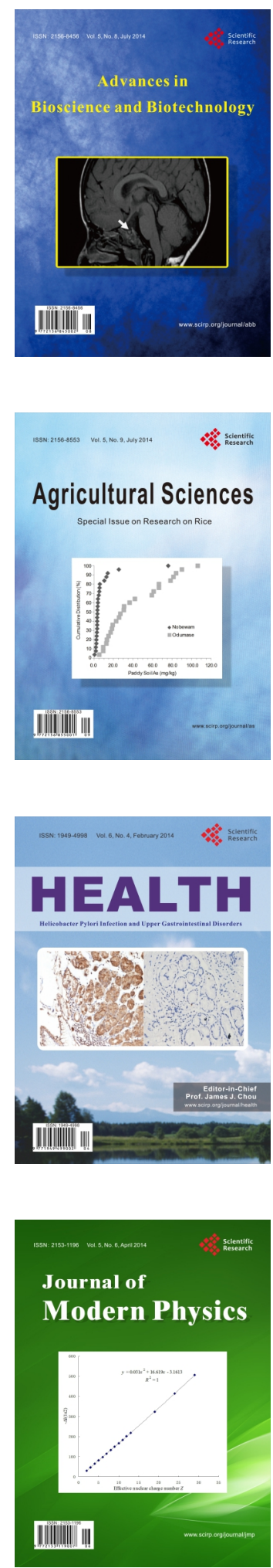
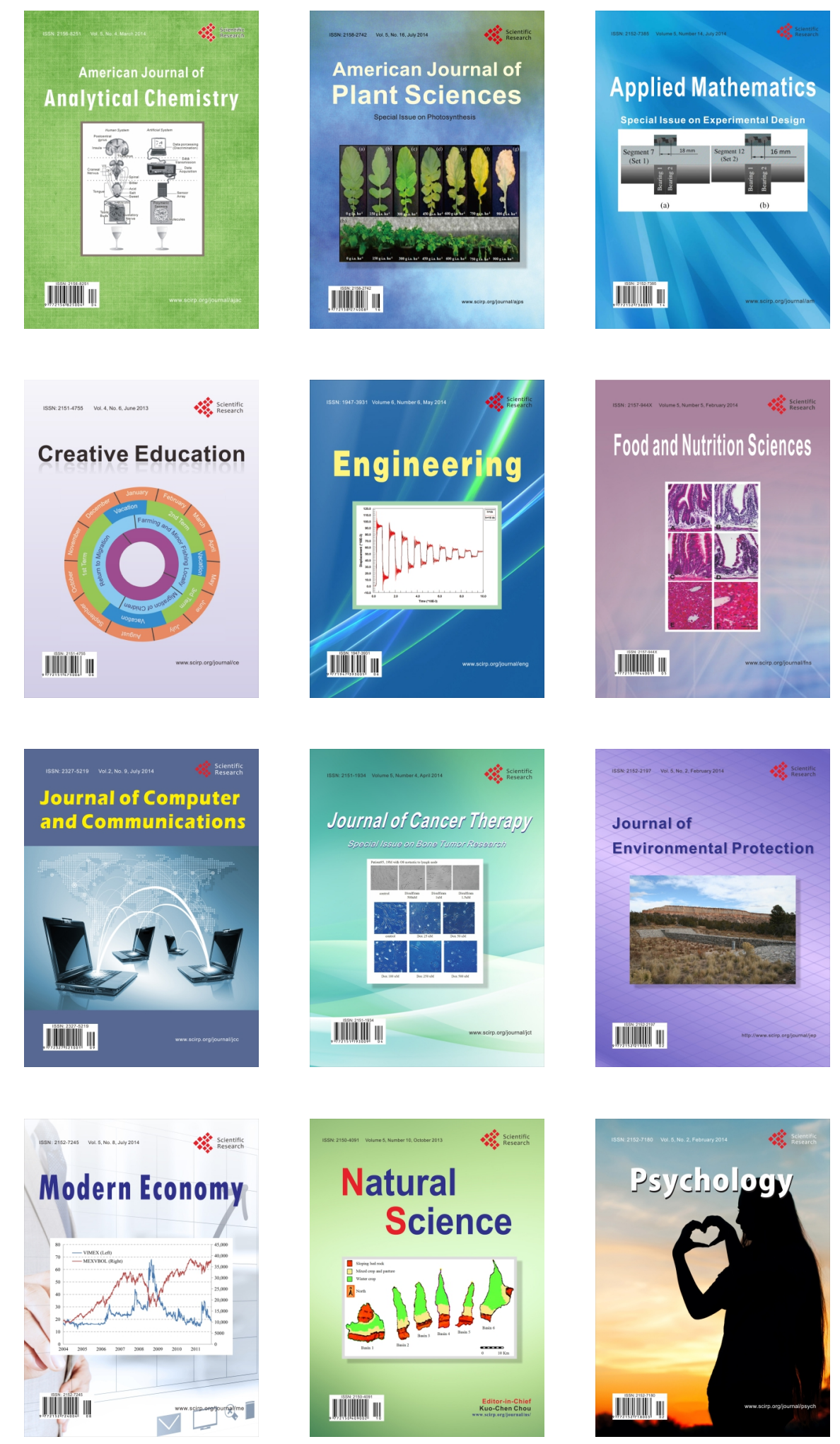